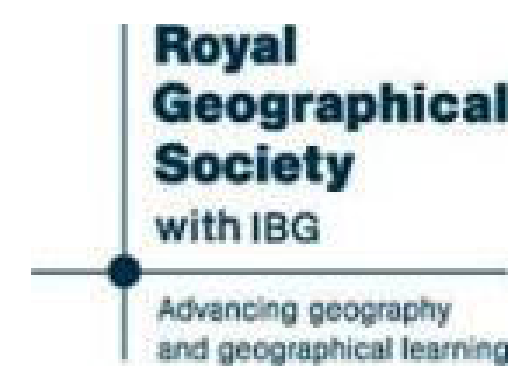

Survey Work on the Frontier between Bolivia and Brazil Author(s): P. H. Fawcett

Source: The Geographical Journal, Vol. 33, No. 2 (Feb., 1909), pp. 181-185

Published by: The Royal Geographical Society (with the Institute of British Geographers)

Stable URL: http://www.jstor.org/stable/1777371

Accessed: 20/01/2015 05:03

Your use of the JSTOR archive indicates your acceptance of the Terms \& Conditions of Use, available at

http://www.jstor.org/page/info/about/policies/terms.jsp

JSTOR is a not-for-profit service that helps scholars, researchers, and students discover, use, and build upon a wide range of content in a trusted digital archive. We use information technology and tools to increase productivity and facilitate new forms of scholarship. For more information about JSTOR, please contact support@jstor.org. 


\title{
SURVEY WORK ON THE FRONTIER BETWEEN BOLIVIA AND BRAZIL.
}

\author{
By Major P. H. FAWCETT, R.A., Chief Bolivian Commissioner.
}

Tre following short sketch of the work completed and in course of operation on the Bolivian and Brazilian frontiers may be of interest, as explanatory of the plans already submitted to the Royal Geographical Society.

It is possibly superfluous to say that a resurvey of the frontier between the two republics became necessary when, in 1903, following on the revolution in the Acre, Bolivia parted with the seventy odd thousand square kilometres of land lying between the Acre and the source of the Javary for a sum of 2,000,000 sterling, and certain modifications of the frontier on the Paraguay river. It was in consequence of this that, early in 1906, I was invited to undertake the exploration of the northern portion of the new frontier, from the falls of the Madeira to the source of the Acre, the geographical conditions of which were but vaguely understood. Mainly, the new frontier rested upon the relation of the upper Acre to parallel $11^{\circ} \mathrm{S}$, and the geographical co-ordinates of the sources of the Iquiry and Rapirran. The actual exploration consisted in the ascent of the Alto Acre, the search for the sources of the abovementioned rivers, and the descent of the Abuna. Three years were anticipated for the work. It actually exhausted nine continuous months of journey, starting from and returning to Riberalta, on the Beni. As in all these out-of-the-way corners of the interior, the chief difficulties lay in food supplies, and in the acquisition of personnel to accompany the surveying party. There were various other difficulties. On the whole, however, these were satisfactorily surmounted, and if one may except the dragging of heavy canoes for six weeks over the rapids of the Alto Acre, and the somewhat trying rains which left the party rarely dry day or night, it was even enjoyable. The river follows the course already determined by Chandless in 1868 .

Hostile savages range the forests to the west of the confluence of the Yaverija, near which rubber exploitation ends. But although they constantly attack the rubber-pickers, they did not molest the party in any way. We were but seven all told in the higher river. Following on the determination of the sources of the Iquiry and Rapirran, in the comparatively high land lying between the Acre and the Abuna, my assistant, Mr. A. F. Chivers, returned to Riberalta and thence home, being unwilling to court the very unhealthy conditions of the latter river after an experience of fever during the previous months. I was, fortunately, able to secure, at a huge price, a very small boat in the upper Abuna, and ultimately descended that river to its confluence with the Madeira, in company with a young Bolivian and three Indians, two of whom subsequently died. The whole region, inundated every year, is villainously

No. II.-February, 1909.] 
unhealthy; nor is the journey otherwise very attractive, for during half its course it is infested with Brazilian criminals who are notoriously loose in their respect for human life, while in the lower half of the river the Pacaguara savages are a constant danger. Moreover, the sucuri or anaconda is unpleasantly prolific. These snakes reach almost fabulous dimensions, according to local accounts. We killed one of 20 metres, and I have the authority of Admiral Guillobel, of the Brazilian commission, for one of 26 metres, killed near Corumba, in the Paraguay. In the Abuna they are credited with man-eating proclivities, and it is certain that their well-worn trails from the swamps suggest dimensions altogether beyond the bounds of European credulity. The tiger of South America, the jaguar, is, too, very common. These beasts are frequently man-eaters in these parts. They invaded the camp pretty well every night, and once $I$ was awakened by one scraping his back as he passed under my hamnock.

Beri beri, the scourge of the Acre, and the whole gamut of tropical fevers are rife, and altogether I am not anxious to revisit this region. Its descent was therefore in the nature of running a gauntlet. The Acre is navigable from December to April up to the confluence of the Yaverija, and the Abuna during the same months. In the dry season they are both merely shallow streams, and much obstructed by snags. At the end of October, 1907, after two and a half months' journey from Riberalta, during which I was wrecked three times in the Beni, I returned to La Paz.

The results of the exploration can be summed up in the willingness of Brazil to accept the Alto Acre as the frontier line from Bahia west, a direct line from Bahia to the source of the Rapirran, and thence the courses of that river and the Abuna to the east. The Iquiry disappears from the treaty, its position having been misunderstood. A joint commission will put up the frontier marks probably in 1911.

On my return to La Paz I was invited by the Goverument to undertake the technical management of the commission to work jointly with the Brazilians in the Paraguay river, and as this offered considerably more interest than the monotony of the Amazonas, I found myself at the beginning of May, 1908, in Corumba, with Mr. I:. G. Fisher and a capable French engineer, Mr. Vandry, as assistants. Here, again, the estimate of time for the completion of the frontier work was altogether in excess of requirements. Within three months, not altogether $I$ am afraid to the liking of our Brazilian colleagues, we had completed the whole of the more important work in the neighbourhood of Corumba, and were brought to a stop by an abnormal unwillingness on the part of the Paraguay waters to fall below inundation level. I therefore decided to leave my French colleague to complete some short geodetic measurements in the lakes of Mandioré, Gaiba, and Uberaba, and represent the technical portion of the commission at the formal erection of the permanent marks 
in the positions fixed, and to take Mr. Fisher and half a dozen peons to discover the true source and course of the mysterious Verde, a river which had baffled the efforts of five Government commissions, and which is a portion of the frontier it was of vital interest to Bolivia to have definite knowledge about.

The Brazilian Commission declined to supply a representative, and politely considered us mad. There were, in truth, somewhat potent reasons for mature consideration. Civilization, such as it is to the north of the flourishing town of Corumba, ends completely at the old ruined city of Matto Grosso, where culminate in a horrible disease, locally known as "corupcion," that long list of infirmities which makes the interior in general, and the negro-inhabited Matto Grosso city in particular, probably the unhealthiest regions in the world. Moreover, anthropophagous savages abound, even within gunshot of the old city. However, these things were never a deterrent to those bitten with the lust of exploration. Suffice it that, after a lengthy journey by river and mule and various vicissitudes, the party entered the Verde from its confluence with the Guaporé. 'The entire river runs through sandstone hills, with deep gorges and endless cataracts. So difficult was the river to ascend that the peons were unable to carry more than their rifles and ammunition, their hammocks, and a theodolite. I had to decide early between all abandonment of all food or an ignominious return. Depending upon at least fish, we were rudely disillusioned, for the water of the river, owing to a species of coarse green grass which covers the bed and lends the river its name, is so unpleasantly affected to the taste that neither fish live in its waters nor game in the surrounding forest. Rain, which fell every day for six weeks, accompanied by violent thunderstorms, became in a sense welcome, for it gave us occasional chances of satisfying a thirst born of struggling thirteen hours a day through desperately thick and thorny undergrowth.

For about two months the party traversed this region without food of any recognized description, even salt, living on the heart of the palmeto palm and on chunta nuts, and by the intervention of Providence alone struggled back to Matto Grosso a mere collection of bones. Three out of six peons subsequently died, and all the dogs, four, failed to survive the journey. The course of the river was, however, determined, and the source referred by triangulation to Matto Grosso city. When we ultimately returned to the lower forest near Matto Grosso, and partially appeased appetite for flesh by a fortuitous encounter with three or four black monkeys, the peons devoured their skins with the fur attached. In Matto Grosso even the half-rotten chaki appeared delicious. The extraordinary difficulties of the journey, apart from food, are more due to the nature of the hills, which are intersected in all directions by deep gorges in the sandstone dropping sheer 100 metres to the numerous small streams which drain the high levels. The plans which accompany 
this indicate generally the physical features of this region. Geologically, the hills are sandstone with outcrops of schist and quartzite and a little granite, rising suddenly from the alluvial plain of the Guaporé to a height of 300 to 700 metres. The savages again left us alone. We were too small a party to menace them in any way possibly. They were around us throughout, and often the night was lit up by their fires. 'I'heir presence necessitated, however, a double sentry every night, for their ways are treacherous, and the tale of their misdeeds long and fearsome. Late in November the remains of the party returned to Corumba, where they were warmly welcomed.

During the present year the commission ends its labours in the fixing of permanent frontier marks at the newly discovered source of the Verde, and the settlement of an outstanding question over Cuatro Hermanos, the most western point, some 100 kilometres to the south. This short sketch may serve as aome indication of the work of the commissions pending more complete reports later on.

South America, which is ummistakably the country of the future, is remarkably little known in the interior, and there are many blank spaces still to be filled. It is full of amazing romances which might repay investigation, of unknown rivers, lakes, and mountains, of unknown races, of riches still untouched, almost beyond imagination. The explorer practically leaves it alone, perhaps because the blank spaces are so difficult to reach. In the low country it is exceedingly unhealthy. Almost without exception the savages are hostile; they are very numerous, and they use poisoned arrows. Time has changed sadly from the days when Chandless could safely explore the Amazonas, and be sure of a friendly welcome from its savage inhabitants. For years, civilized and savage have shot one another at sight. The perils of the rivers are perhaps as in no other country. The "perania," the "candaru," the "mungruyu" or fresh-water shark, the anacondas and alligators associate any accident with unpleasant possibilities. The forests in places are obsessed with poisonous snakes, and occasionally even the ordiuarily timid jaguar is savage. Civilized man in the interior knows no laws.

Outside the trade-routes there are no roads for animals, and it is difficult and often impossible to secure even a few peons for the carrying of stores. Labour is everywhere scarce, and peons are unwilling to risk their lives in unknown parts. Later these things will change. Railways are creeping up from the south, and their tentacles are clutching at the wild interiors of Brazil and Bolivia, while the Madeira railway and the North-West railway from San Pablo to Corumba are under construction. The republics of South America are all awakening from their indolence to encourage immigration. Movement and trade in the navigable rivers are increasing. Resources, vegetable and mineral, are immeasurable. The climate of the uplands is splendid. The wretched policy which created a slave trade, and openly encouraged a reckless 
slaughter of the indigenous Indians, many of them races of great intelligence, and imbued them with a deadly vengeance against the stranger, is giving place to wiser and more humane treatment. But advance is already making more acute the question of frontiers, and South American Frontier Commissions are likely to be much heard of in the future. They should provide interesting additions to the Geographical and Ethnological history of the world, and incidentally bring Europe more into touch with the cultured and enlightened peoples of this great continent.

\section{THE ITALIAN EARTHQUAKE OF DECEMBER 28, 1908.}

\section{By R. D. OLDHAM.}

Tile earthquake of December 28, 1908, stands pre-eminent in one respect, for it seems impossible to doubt that when the loss of life is finally counted up it will reach a larger total than has ever yet been due to a single earthquake. Up till now the Yeddo earthquake of 1703, with its reputed death-roll of 200,000 , had stood in a class by itself, only in the crowded cities of China had 100,000 been reached, and in Europe tens of thousands had sufficed. The Calabrian earthquake of 1693 is said to have accounted for 93,000 lives in Calabria and Sicily, that of 1783 for 30,000 as the direct result of the earthquake and for another 10,000 by exposure, famine, and sickness, but the recent earthquake's death-roll can hardly have been less than 200,000 without counting the indirect consequences of the earthquake. In face of a calamity of this magnitude, and the magnificent, if somewhat agitated, outburst of charity which it has evoked, a calm investigation of such accounts as have reached us, and an attempt to extract from them information of scientific interest and value, must savour of cold-bloodedness; yet the human suffering will pass, the ruined cities will be rebuilt, for their existence and location are alike inevitable, but rebuilt, it is to be hoped, in a manner which will not make them death-traps, as were those which have disappeared. Not a tithe, nor the iithe of a tithe, of the loss of life on the morning of December 28 would have occurred had not the very sensible and practical regulations devised and enforced by the Neapolitan Government after the earthquake of 1783 been allowed to fall into abeyance; for this question of building construction in earthquake-shaken countries is no new one, and the simple instructions issued in 1784 might be adopted almost unchanged at the present day, with modifications in detail, consequent on the introduction of materials and methods of construction, which were not available a century ago.

Turning to the earthquake proper, the principal interest is in the comparision with earlier earthquakes in the same region, and especially with the great one of 1783 , of which several detailed accounts by acute observers are extant. The area of destruction in each case seems to have 